\title{
Transient cortical blindness after coronary artery angiography
}

Przejściowe korowe zaburzenia widzenia po zabiegu koronarografii

\author{
Michał Terlecki', Wiktoria Wojciechowska', Marek Rajzer ${ }^{1}$, Artur Jurczyszyn², Stanisława Bazan-Socha ${ }^{3}$, \\ Leszek Bryniarski', Danuta Czarnecka ${ }^{1}$
}

${ }^{1} 1^{\text {st }}$ Department of Cardiology and Hypertension, Jagiellonian University Medical College, Krakow, Poland

2Department of Hematology, University Hospital, Krakow, Poland

${ }^{3}$ Department of Allergy and Immunology, $2^{\text {nd }}$ Chair in Internal Diseases, Jagiellonian University Medical College, Krakow, Poland

Postep Kardiol Inter 2013, 9, 1 (31): 105-108

DOI: $10.5114 /$ pwki.2013.34036

\begin{abstract}
Coronary angiography is the current gold standard for the diagnosis of ischemic heart disease and therefore the prevalence of percutaneous coronary procedures such as angiography and angioplasty is high. The occurrence of cerebral complications after coronary angiography and coronary angioplasty is low and it mainly includes transient ischemic attack and stroke. The prevalence of transient cortical blindness after X-ray contrast media is low and it is usually seen after cerebral angiography. Until now only a few cases of transient cortical blindness have been described after coronary artery angiography. Regarding the spread of coronary angiography worldwide and in Poland this complication is uniquely rare. A 32-year-old man with multiple extrasystolic ventricular arrhythmia suggesting Brugada syndrome diagnosis according to morphology of the left bundle branch block and with decreased left ventricular ejection fraction was admitted to the First Department of Cardiology and Hypertension, Medical College of the Jagiellonian University in Krakow. Coronary angiography was performed in order to exclude ischemic etiology of the observed abnormalities. No arteriosclerotic lesions were found in coronary arteries. Transient cortical blindness was observed directly after angiography which may have been caused by the neurotoxic effect of the used X-ray contrast medium. In ophthalmologic and neurologic examination as well as in the cerebral computed tomography scan no pathologies were found. Visual impairment disappeared totally within several hours.
\end{abstract}

Key words: cortical blindness, contrast media, coronary angiography.

\section{Streszczenie}

Koronarografia jest obecnie złotym standardem w diagnostyce choroby niedokrwiennej serca, w związku z czym częstość wykonywania przezskórnych zabiegów wieńcowych, tj. angiografii oraz angioplastyki, jest duża. Powikłania naczyniowo-mózgowe po koronarografii i koronaroplastyce są rzadkie i zazwyczaj obejmują przejściowe ataki niedokrwienne oraz udary mózgu. Częstość występowania przejściowych korowych zaburzeń widzenia po środkach kontrastowych jest niewielka. Zaburzenia te stwierdza się zazwyczaj w przypadku angiografii naczyń mózgowych. Przemijające korowe zaburzenia widzenia po zabiegu koronarografii opisano dotychczas jedynie u kilkunastu pacjentów. Biorąc pod uwagę szerokie i częste zastosowanie koronarografii na świecie, a także w Polsce, jest to więc wyjątkowo rzadkie powikłanie. Do I Kliniki Kardiologii i Nadciśnienia Tętniczego Szpitala Uniwersyteckiego w Krakowie przyjęto 32-letniego chorego z licznymi pobudzeniami dodatkowymi o morfologii bloku lewej odnogi pęczka Hisa, ze zmianami w spoczynkowym badaniu elektrokardiograficznym sugerującymi podejrzenie zespołu Brugadów, a także z obniżoną frakcją wyrzutową lewej komory serca. W celu wykluczenia podłoża niedokrwiennego obserwowanych nieprawidłowości chorego zakwalifikowano do koronarografii. W wykonanym badaniu nie stwierdzono zmian w tętnicach wieńcowych. Przebieg zabiegu był powikłany przejściowymi korowymi zaburzeniami widzenia, które odniesiono do neurotoksycznego działania kontrastu. W przeprowadzonej wówczas tomografii komputerowej mózgowia nie zaobserwowano patologii, a w badaniu okulistycznym i neurologicznym nie odnotowano przyczyn zgłaszanych dolegliwości. Zaburzenia widzenia ustąpiły samoistnie w ciągu kilkunastu godzin.

Słowa kluczowe: ślepota korowa, środki kontrastowe, koronarografia.

\section{Corresponding autor/Adres do korespondencji:}

Michał Terlecki MD, PhD, $1^{\text {st }}$ Department of Cardiology and Hypertension, Jagiellonian University Medical College, 17 Kopernika St, 31-501 Krakow, Poland, tel./fax: +48 1242473 00, e-mail: michalte@poczta.onet.pl

Received: 25.11.2012, accepted: 14.01.2013. 


\section{Introduction}

Coronary angiography is currently the gold standard in the detection of ischemic heart disease, which is why percutaneous procedures such as angiography or percutaneous coronary intervention $(\mathrm{PCl})$ are frequently performed. Cerebrovascular complications of coronary angiography and $\mathrm{PCI}$ are rare and usually include transient ischemic attacks (TIA) or stroke and affect approximately $0.4 \%$ of all patients undergoing PCI [1, 2]. These complications occur more often in some specific groups of patients: in the elderly, in female patients, in patients with diabetes mellitus type 2 , in those with diffuse atherosclerosis, in patients undergoing coronary artery bypass grafting, in patients with peri-procedural complications (artery dissection) and in patients with no-reflow who often require intra-aortic counterpulsation [2].

Cortical visual impairment following administration of a contrast agent occurs in $0.3-1.0 \%$ of patients undergoing angiography of the cerebral arteries [3]. In the case of coronary angiography the rate is $0.21-0.45 \%$ [4]. This is a very rare complication given the widespread and frequent use of coronary angiography throughout the world, including Poland (around 3500 procedures/million inhabitants) [5]. Patients at risk of cortical visual impairment include those after previous coronary artery bypass grafting and patients with renal failure. The exact mechanism leading to the onset of cortical visual impairment remains unknown. The most likely explanation of this phenomenon is an increase of permeability of the blood-brain barrier and a direct neurotoxic effect of contrast agents $[6,7]$.

\section{Aim}

The aim of the study was to present a case of a transient cortical visual impairment after coronary angiography in a patient admitted to diagnose the causes of arrhythmia.

\section{Case report}

A 32-year-old patient suspected of having Brugada syndrome (syncope with complete loss of consciousness, I point elevation in leads V1-V3 on resting electrocardiogram and sudden cardiac death of the father at the age of 49 years), with right ventricular extrasystoles was admitted to the $1^{\text {st }}$ Department of Cardiology and Hypertension of the University Hospital in Cracow for the ajmaline challenge. The result of the study was inconclusive for the Brugada syndrome. Because of decreased left ventricular ejection fraction on echocardiography (EF around 40\%) the patient was qualified for coronary angiography, which did not reveal changes in coronary arteries (Figure 1). Coronary angiography was performed through the right femoral artery with a $6 \mathrm{~F}$ vascular sheath and Judkins diagnostic catheters and was preceded by local anesthesia with $1 \%$ lignocaine solution. The procedure lasted $20 \mathrm{~min}$ and the patient remained hemodynamically stable for the whole time. Approximately $100 \mathrm{ml}$ of a nonionic, hypo-osmolar contrast agent (Utrav- ist) was used for the procedure. The patient did not have a history of previous procedures with contrast medium administration. During coronary angiography the patient reported visual impairment without any other focal symptoms. In 15 min time the patient completely lost vision. He was conscious, with good verbal contact, good auto- and allopsychic orientation and good respiratory and circulatory condition (during the procedure and immediately after the procedure blood pressure was 130/80 mm Hg, heart rhythm $60 \mathrm{bmp}$ ). Directly after the coronary angiography the patient underwent neurological and ophthalmological consultation. Apart from binocular blindness there were no other abnormalities. Urgently performed computed tomography of the head (without contrast medium) did not reveal any pathology (Figure 2). Visual impairment resolved completely on the first day after the coronary angiography.

Based on the clinical picture (numerous ventricular extrasystoles with LBBB morphology, akinetic area within the right ventricular free wall and reduced right ventricular ejection fraction (40\%) on magnetic resonance imaging (MRI) with reduced left ventricular ejection fraction on echocardiography and sudden, unexplained death of the father) a diagnosis of idiopathic dilated cardiomyopathy was made, which may be an early manifestation of arrhythmogenic right ventricular cardiomyopathy with left ventricular involvement. However, during the stay in the clinic there was no clear evidence favoring the diagnosis of arrhythmogenic right ventricular cardiomyopathy. Genetic samples were obtained from the patient to test for arrhythmogenic right ventricular cardiomyopathy and Brugada syndrome and they are currently under determination. The patient was discharged home on the third day after the coronary angiography in a good general condition and without any symptoms.

\section{Discussion}

In the presented case the differential diagnosis should primarily include the occurrence of arrhythmias in a patient with a history of recurrent syncope and arrhythmia and a secondary ischemia of the central nervous system. However, on the coronary angiography and in the following hours the patient was under constant ECG, blood pressure and blood oxygenation monitoring. No abnormalities were recorded. As the next step it should be assumed that the described reaction had an allergic or non-allergic hypersensitivity character after administered pharmacological agents. The patient received $2 \%$ lignocaine solution (subcutaneous administration before the procedure) and a nonionic low-osmolar intravenous contrast agent. Side effects observed after local application of anesthetic agents occur within several, maximally 20 min following administration. These include dizziness, psychomotor agitation, excessive sweating, tachycardia, double vision, tinnitus, body tremor, slurred speech and fainting. They are usually associated with drug overdose or accidental admin- 


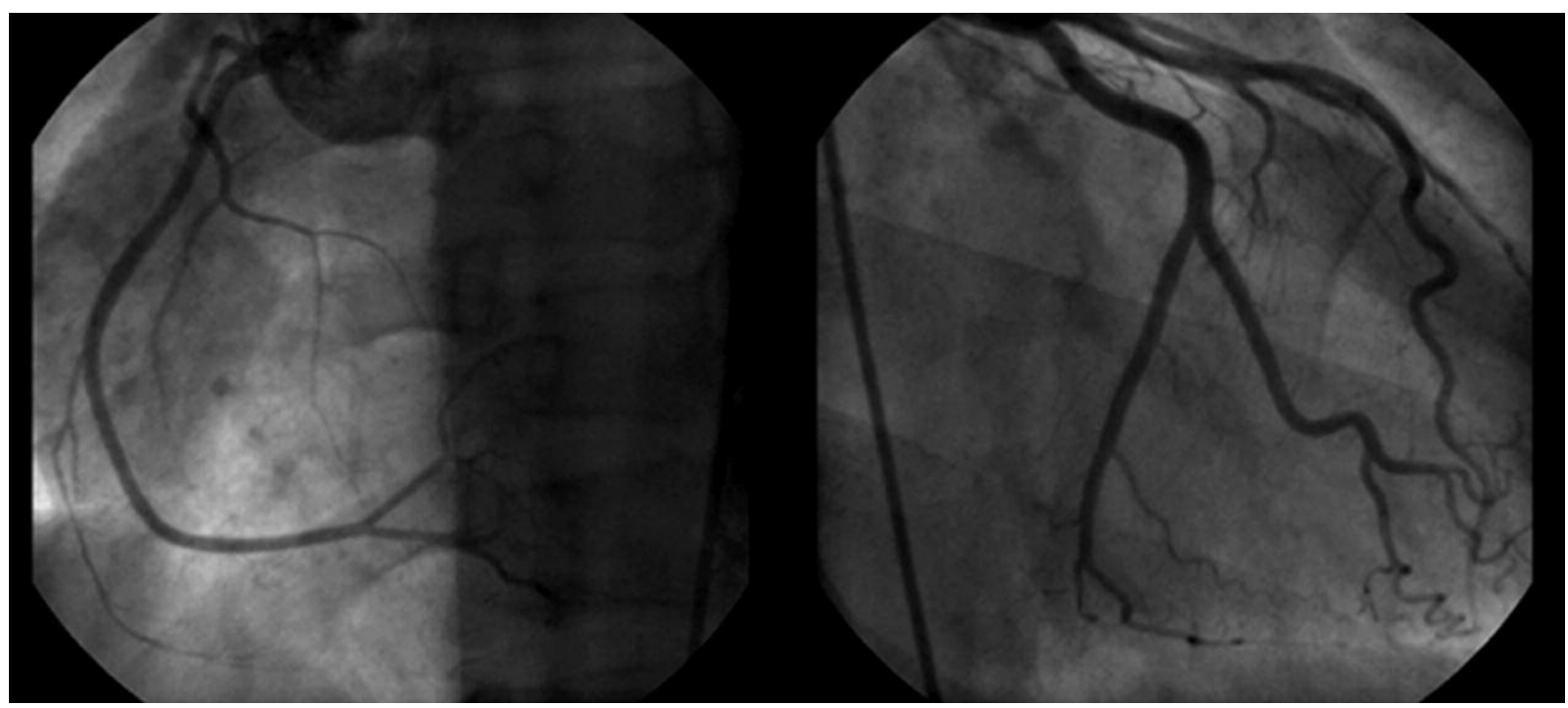

Fig. 1. Coronary angiography

Ryc. 1. Badanie koronarograficzne

istration of the drug directly into the vessel [8]. It seems that the described loss of vision should not be related to the use of lignocaine, although there are isolated reports on such a complication in the literature [9]. In our patient clinical symptoms occurred after approximately $30 \mathrm{~min}$ of local anesthesia, and had a clear temporal relationship with the administration of the nonionic contrast agent. Intravenous contrast agents are highly concentrated solutions of low molecular weight. They diffuse out of the bloodstream at a rapid pace and $70 \%$ of the dose disappears from plasma within about 2-5 min after the administration [8]. Epidemiologic studies conducted in the 1980s demonstrated that the frequency of adverse reactions after injection of nonionic low-osmolar contrast agents is $0.7-3.1 \%$, of which life-threatening reactions account for $0.02-0.04 \%$ of cases [8]. Most adverse reactions are characterized by a low intensity and are associated with non-specific (non-allergic) influence of the agent particles directly on the cellular membranes [8]. These are most often mastocytes, present in the skin and in the connective tissue, which undergo activation and degranulation. It results in anaphylactic reaction with the presence of skin changes and symptoms of respiratory, gastrointestinal and circulatory system involvement. The symptoms of central nervous system involvement include syncope and seizures, which are related to cerebral ischemia. None of the typical symptoms suggesting the presence of an anaphylactic reaction were present in our patient.

The pathophysiology of transient cortical visual impairment is not clear. Most likely, the blood-brain barrier becomes damaged, which allows the contrast agent to express a direct neurotoxic effect on nerve cell membranes in the occipital lobes [1]. In the majority of cases described so far, the computed tomography image showed post-contrast enhancement in the occipital lobe, which may be related to body

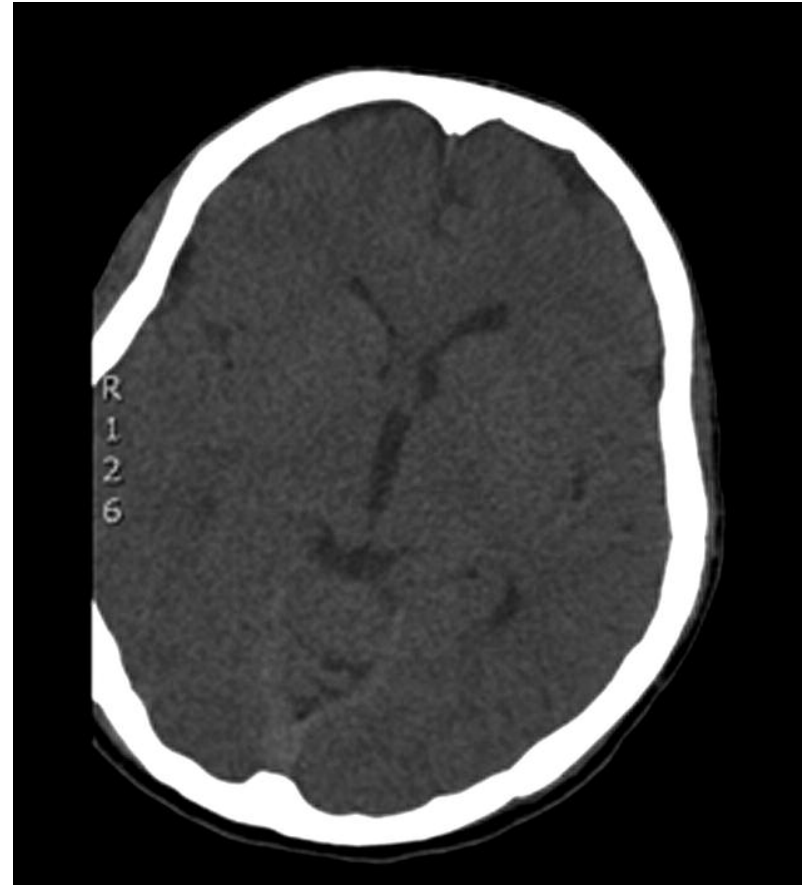

Fig. 2. Computed tomography

Ryc. 2. Badanie tomograficzne głowy

position during coronary angiography. Additionally it was demonstrated that posterior cerebral circulation is most susceptible to the above pathologies, which may result from difference in sympathetic innervation $[10,11]$. The risk of transient cortical blindness increases with the use of highly osmolar contrast agents, but the complication may also occur after application of nonionic, low-osmolar substances [12], as in our case. According to the data from the drug registration office the possible complications involv- 
ing the central nervous system and related to Ultravist (iopromide) use include dizziness, headache, confusion or agitation, amnesia, impaired speech, hearing and vision as well as transient blindness. These abnormalities occur more frequently in patients with previously diagnosed disease of the central nervous system and in patients undergoing angiography of the cerebral arteries. In the latter situation concentration of the contrast agent in the cerebral circulation is higher [13]. The risk factors also include renal failure and coronary bypass from the internal mammary artery (the origin of the internal mammary artery from the subclavian artery close to the origin of the vertebral artery may favor the passage of a large amount of contrast agent to the left vertebral artery during bypassography of the left internal mammary artery) [6, 7]. Our patient was not at risk of cortical visual impairment. However, based on the family history and clinical observation it is possible that he might have a congenital defect of ion channels of the cellular membranes, which might cause abnormalities in the electrical activity of neurons, and thus the conduction of nerve impulses.

An attempt to characterize the clinical features of patients with documented cortical visual impairment was made by Frantz during the EuroPCR congress in 2006 [6]. The presented data included 15 patients and suggested a higher prevalence of the complication in men than in women. The mean age of patients in the study was $54 \pm 7.6$ years, more than half of them had confirmed arterial hypertension (9 patients), 1 patient had impaired renal function and 9 patients had a history of exposure to contrast agents. The amount of contrast medium used for the procedures ranged from $75 \mathrm{ml}$ to $400 \mathrm{ml}$. Return to normal vision lasted from 15 min to 5 days.

A differential diagnosis of transient cortical visual impairment after coronary angiography should include cerebral embolism, cerebral vasospasm, hysterical blindness and post-contrast hypotension [6].

There is no determined management strategy for this complication. Neurological and ophthalmological consultation and imaging examinations of the brain (computed tomography and magnetic resonance) are necessary for the diagnosis. Strict control of blood pressure and diuresis seem to be relevant in the fast resolution of symptoms, although there are no data on the influence of hydration or fluid therapy and diuresis control on the described complication.

\section{Conclusions}

Transient cortical visual impairment is a rare, rapidly progressing complication of angiography. Although the exact mechanism of cortical visual impairment in unknown, the interruption of the blood-brain barrier and direct neurotoxic effect of contrast agent are the most likely causes of this abnormality. Neurological and ophthalmological consultation and imaging examinations of the brain (computed tomography and magnetic resonance) seem necessary for the diagnosis. Currently, there is no determined management strategy for this complication.

\section{Acknowledgments}

The study was performed in the 1st Department of Cardiology and Hypertension of the Jagiellonian University Medical College.

\section{References}

1. Lim KK, Radford DJ. Transient cortical blindness related to coronary angiography and graft study. Med J Aust 2002; 177: 43-44.

2. Fuchs S, Stabile E, Kinnaird TD, et al. Stroke complicating percutaneous coronary interventions: incidence, predictors, and prognostic implications. Circulation 2002; 106: 86-91.

3. Horwitz NH, Wener L Temporary cortical blindness following angiography. J Neurosurg 1974; 40: 583-586.

4. Borowik H, Kułakowska A, Drozdowski W, et al. Transient cortical blindness - a complication after coronary angiography. Pol Merk Lek 2008; 24: 430.

5. Rużyłło W, Gil RJ, Witkowski A. Coronary angiography and percutaneous coronary interventions in Poland between 1993 and 2004. Analysis from the perspective of the chairmen of the Working Group on Interventional Cardiology of the Polish Cardiac Society. Postep Kardiol Inter 2005; 1: 3-7.

6. Frantz WM. Cortical blindness following coronary angiography in a patient with LIMA bypass graft and end stage renal failure. Proceedings of EuroPCR 2006, May 21-24; Paris.

7. Yazici M, Ozhan H, Kinay O, et al. Transient cortical blindness after cardiac catheterization with lobitridol. Tex Heart Inst J 2007; 34: 373-375.

8. Skórne objawy nadwrażliwości na leki. Jenerowicz D, CzarneckaOperacz M, Silny W. Termedia, Poznań 2009.

9. Sawyer RJ, von Schroeder H. Temporary bilateral blindness after acute lidocaine toxicity. Anesth Analg 2002; 95: 224-226.

10. Borghi C, Saia F, Marzochi A, et al. The conundrum of transient cortical blindness following coronary angiography. J Cardiovascul Med 2008; 9: 1063-1065.

11. Kermode AG, Chakera T, Mastaglia FL. Low-osmolar and non-ionic X-ray contrast media and cortical blindness. Clin Exp Neurol 1992; 29: 272-276.

12. Saigal G, Bhatia R, Bhatia S, et al. MR findings of cortical blindness following cerebral angiography: is this entity related to posterior reversible leukoencephalopathy? Am J Neuroradiol 2004; 25 : 252-256.

13. Wayne NJ. Ultravist (iopromide) prescribing information. Bayer HealthCare Pharmaceuticals, Inc. 2007. 12. 18-08. 